\title{
Applications of chiral spirocyclic phosphoric acid in the synthesis of natural products
}

\author{
Fan Yang ${ }^{1 *}$ \\ ${ }^{1}$ School of pharmaceutical Science and Technology, Tianjin University, Tianjin, 300072, China
}

\begin{abstract}
With a 10 years development, chiral spirocyclic phosphoric acids (SPAs) have attracted a substantial amount of attention from the synthetic organic chemistry community. This kind of small molecule organic catalysts has some advantages like easy to obtain, no transition metal and wide application range. Because of avoiding the use of toxic substances which are limited in the process of drug synthesis, a large number of studies pay attention to the key structures (such as indole, carbozole.) containing pharmacological active components in natural products. And most of them get a excellent result in yields (more than $80 \%$ yield) and enantioselectivities (more than $90 \%$ ee). These studies can provide new pathways to nature products.
\end{abstract}

\section{Introduction}

Chiral molecules exist widely in natural products and bioactive molecules. Chiral chemistry has been attracted much attention and developed rapidly in chiral medicine, pesticides, special materials and other fields. In 2004, Akiyama group reported the first chiral Brønsted acid catalyzed enantioselective Mannich reaction, which made people pay their attention to BINOL and a series of BINOL-phosphoric acid catalysts with BINOL framework [1]. Because of the significant advantages of BINOL catalyst over other chiral catalysts, it has been developed into a powerful catalyst for asymmetric controlled synthesis of a variety of organic compounds. Compared with metal catalysts, chiral phosphoric acid catalysts are cheaper, easier to prepare, and avoid transition metals, especially some toxic substances that cannot be used in drugs; compared with other organic catalysts, they are more applicable [2]. In the following 16 years, several chiral phosphoric acid catalysts with different skeletons have been developed, such as BINOL, H8- BINOL, VAPOL, SPA. [3-5](Figure1). Spirodiindene based chiral phosphoric acid catalyst first appeared in F-C reaction, which was catalyzed by SPA, and published by Lin Xufeng in August 2010. [6] Using chiral 1,1'-spirobiindane-7,7'-diol as starting material, the corresponding catalysts were synthesized in four steps (Scheme 1). And Lin patented it in October [7]. In September of the same year, Benjamin list group also published the asymmetric transacetal reaction catalyzed by SPA [8].<smiles></smiles>

BINOL<smiles></smiles>

$\left[\mathrm{H}_{8}\right]-\mathrm{BINOL}$<smiles>O=P(O)(O)Oc1c(-c2ccccc2)cc2ccc3ccccc3c2c1-c1c(-c2ccccc2)cc2ccc3ccccc3c2c1-c1ccccc1</smiles><smiles>[R]c1ccc2c(c1OP(=O)(O)Oc1c([R])ccc3c1C1(CCC3)CCC1)CC2</smiles>

VAPOL

Figure 1. Typical chiral phosphoric acid catalysts 

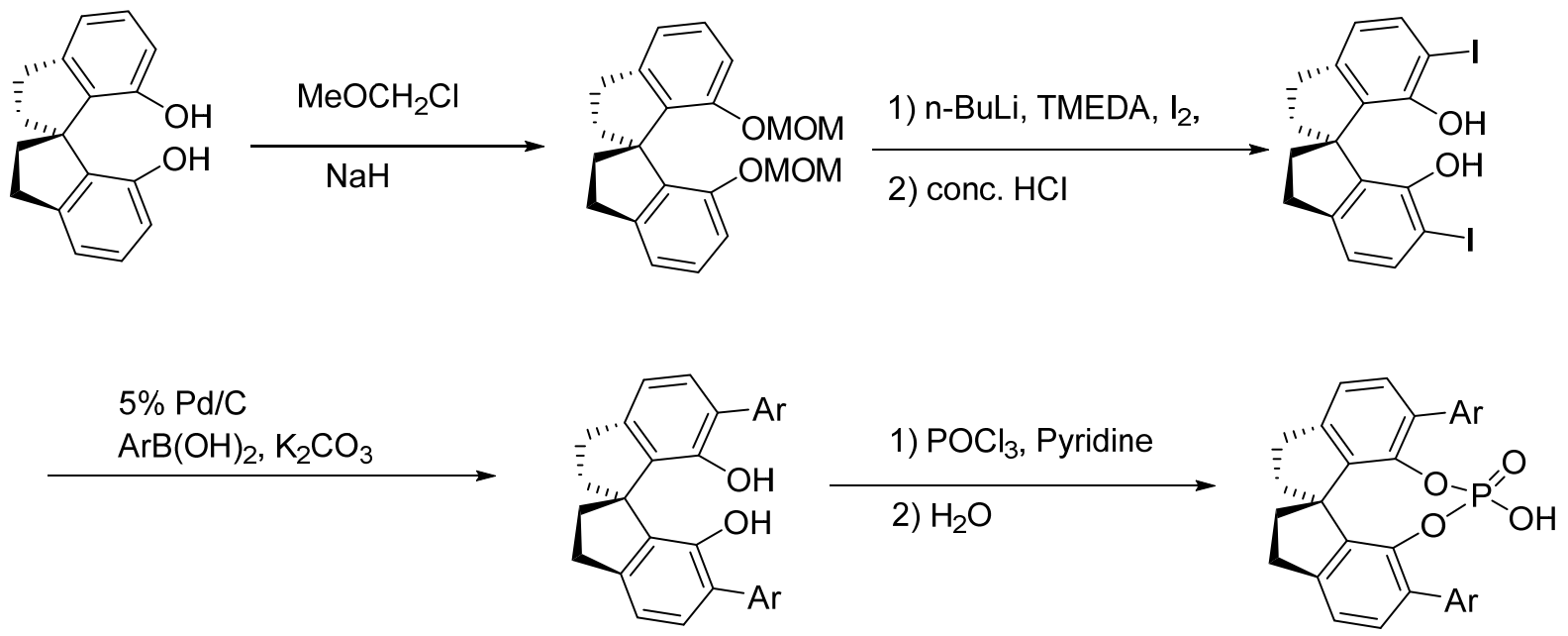

Scheme 1. Route towards the synthesis of SPAs.

In the following 10 years, the application of SPA catalysts has developed rapidly. Through many research and exploration, the intermediate transition states of chiral phosphoric acid catalysts can be roughly divided into two categories, One is bifunctional activation (Figure 2), and the other is Ion-pairing activation (Figure 3)[9-10]. With the development of SPA, many important asymmetric catalytic reactions such as Pictet-Spengler reaction, Fisher indolization, Diels-alder reaction and Ugi reaction have been realized[11-14].In 2019, Lin Xufeng's group obtained the first chiral phosphoric acid catalyzed axial chiral N-arylindole by using the second generation SPA catalyst.[15] A series of axially chiral arylindoles (up to 99\% ee) were obtained in high yield (up to 93\%) (scheme 2 ). The realization of these reactions not only provides a new idea for the synthesis of a variety of natural products or bioactive chiral molecules, but also expands a new space for the development and application of SPA catalysts.

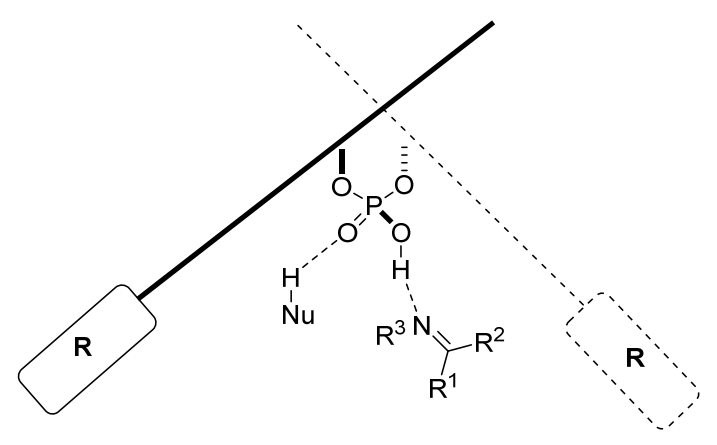

Figure 2. Bifunctional activation

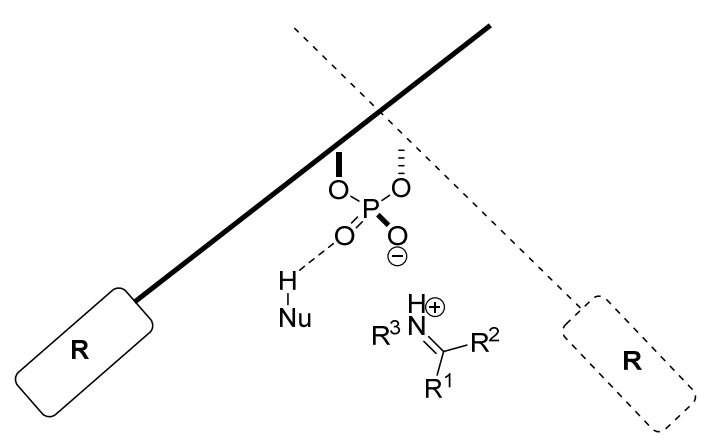

Figure 3. Ion-pairing activation 


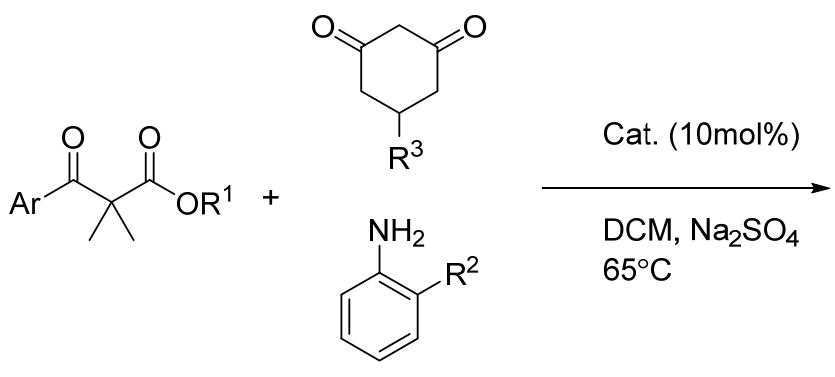

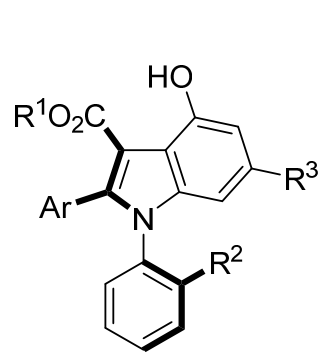

up to $93 \%$ yield up to $99 \%$ ee<smiles>CC(C)(C)c1cccc(Br)c1OP(=O)(O)Oc1c(Br)ccc2c1[C@]1(CCCC1(C)C)C2</smiles>

Cat. $\mathrm{Ar}=\mathrm{Ph}$

Scheme 2. Enantioselective synthesis of axially chiral N-Aryl indoles

\section{Common catalytic reaction types}

\subsection{Cyclization reaction}

SPA can catalyze a variety of cyclization reactions, which provide ideas for the chemical synthesis of a variety of bioactive natural products.

Since Diels and alder published the cyclization of dienyl and dienophile in 1928, D-A reaction has been widely used in the synthesis of bioactive cyclic molecules. With the development of asymmetric hetero D-A reactions, many ideas have been provided for the efficient, regioselective and stereoselective construction of various chiral pure heterocycles [16]. In 2013, Zhu Guangyu and sun Jianwei first discovered the asymmetric catalytic three component aza-Diels- alder reaction (Scheme 3). They realized the rapid assembly of complex polycyclic alkaloids containing indole, tetrahydroquinoline and tetrahydroisoquinoline from simple non chiral materials [17]. The highest yield (85\%), ee value (98\%) and D.R. > 99:1:0:0 were obtained by the reaction of indole and otrimethyl ester benzaldehyde in the presence of aniline and catalzed by $2.5 \%$ mol SPA catalyst. A large number of complex molecules containing key subunits such as tetrahydroquinoline and tetrahydroisoquinoline have important biological activities[18-22]. This new catalytic asymmetric multicomponent reaction is of great significance for the synthesis of many alkaloids and drug development.<smiles></smiles><smiles>[R]c1ccc2c(c1)NC1c3c(OC)cc(OC)cc3N3C[C@H](CO)c4ccccc4[C@H]2[C@@H]13</smiles><smiles>O=P(O)(Oc1ccccc1)Oc1c(Br)ccc2c1Oc1c(Br)cccc1C2</smiles>

Cat. $\mathrm{Ar}=2,4,6-(\mathrm{Pr})_{3} \mathrm{C}_{6} \mathrm{H}_{2}$

Scheme 3. Asymmetric multicomponent Aza-Diels-Alder reaction

Chiral 2,3-disubstituted-2,3-dihydrobenzofurans are common fragments of many bioactive molecules and natural products [23-28]. In 2016, Géraldine Masson's group developed the $[3+2]$ cycloaddition of quinones with olefins and sulfoxide carbamates under the catalysis of SPA, and obtained 3-amino-2,3-dihydrobenzofuran, which achieved good diastereoselectivity and excellent enantioselectivity [29] (Scheme 4). They obtained a template reaction with $99 \%$ yield, $99 \%$ ee and 6:1 Dr. In addition, the Géraldine Masson's group also realized the asymmetric tandem oxidative $[3+2]$ cycloaddition. Hydroquinone was used as the starting material, phenyliodo (III) diacetate (PIDA) and chiral phosphoric acid were carried out in the same reactor (Scheme 5).<smiles>[R]C=CNC(=O)O[R2][R]([H])([H])[H]</smiles><smiles>O=P1(O)Oc2c(Br)ccc(Br)c2[C@]23CC[C@@H](CC2)c2ccc(Br)c(c23)O1</smiles>

Ar=1-naphthyl

Cat.

Scheme 4. Asymmetric [3+2] cycloaddition of quinones with ene- and thioene-carbamates 


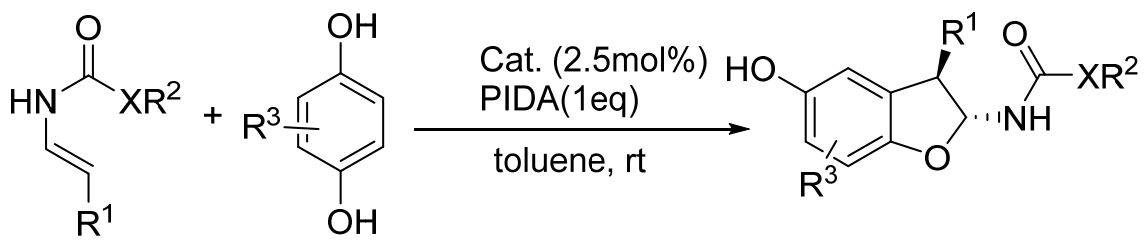

Scheme 5. Asymmetric tandem oxidative cycloaddition<smiles>O=P(O)(O)Oc1c(Br)ccc2c1C1CCC2CC1</smiles>

Ar=1-naphthyl

Cat.
Paeoveitol is one of the main antipsychotic components of Radix Paeoniae Rubra.[30-31] In 2017, Chen Jijun's group reported for the first time the enantioselective 6-step total synthesis of Paeoveitol with an overall yield of $42 \%$ [32], and the best result was the 7- step total synthesis published by Xie Zhixiang's group with an overall yield of $26 \%$ [33]. SPA catalyzed hetero Diels alter reaction, as a key step, provides high yield (up to $95 \%$ ) and good corresponding selectivity (up to $90 \%$ ee). (Scheme 6)<smiles>Cc1cc2occ(CO)c2cc1O</smiles><smiles>O=P(O)(O)Oc1c(Br)ccc2c1C1CC[C@H]2CCC1Br</smiles>

Ar=2-naphthyl

Cat.

Scheme 6. $[4+2]$ Hetero-Diels-Alder reaction

Cyclic ethers are ubiquitous in natural products and are commonly used in organic synthesis [34-36]. In 2018, Terada Masaharu's group published a report on the synthesis of chiral seven membered cyclic ethers via the intrinsic homology of Nicholas reaction. Under the catalysis of SPA, the racemic diols were cyclized to obtain good yield and good enantioselectivity [37]. (Scheme 7)<smiles>O=C(O)CCCCCCC(=O)OC(=O)O</smiles><smiles>CCCCCCCCCC</smiles><smiles>[R]C1OCCCC(COC(=O)OCc2ccccc2)=C1C(=O)O</smiles>

Scheme 7. Synthesis of seven-membered cyclic ethers

Trisubstituted chromone frameworks have three adjacent chiral centers, which are ubiquitous in many natural products and bioactive molecules[38-40]. In 2020, Yuan Weicheng group (scheme 8) and Shao Zhihui group (scheme 9) published papers on the use of chiral phosphoric acid catalyst to obtain chiral 2,3,4trisubstituted chromones with high stereoselectivity through [4 +2$]$ cycloaddition [41-42]. These methods have good yield and enantioselectivity, and have a wide range of applications. Two of the groups used 1 - ((2-aryl) vinyl) naphthalene-2-phenol as raw material for asymmetric synthesis of trisubstituted chromones, however, different catalysts were selected through different specific conditions, and good catalytic effect was achieved. At the same time, the two groups have also carried out experiments and discussions on the catalytic mechanism. (scheme 10) by protecting the hydroxyl group and not reacting, it is proved that the free hydroxyl group of the two substrates is necessary for the reaction, In addition, the chiral phosphoric acid catalyst was activated to dehydrate O-hydroxybenzyl alcohol to o-quinolone formamide, At the same time, 1- ((2-aryl) vinyl) naphthalene-2-phenol was activated to increase the nucleophilicity. SPA was used as a bifunctional catalyst to combine the two intermediates into a transition state by hydrogen bonding. 
<smiles>Oc1ccc2ccccc2c1/C=C/c1ccccc1</smiles><smiles>Oc1ccccc1C(O)c1ccccc1</smiles>

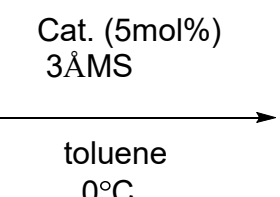
$0^{\circ} \mathrm{C}$<smiles>Oc1ccc2ccccc2c1[C@@H]1Oc2ccccc2[C@@H](c2ccccc2)[C@H]1c1ccccc1</smiles>

Yield $99 \%$ ee $\quad 97 \%$<smiles>O=P(O)(O)Oc1c(Br)ccc2c1Oc1c(Br)cccc1CC2</smiles>

Cat.

Ar $=$ 9-anthryl

Scheme 8. The research of Wei-Cheng Yuan's group<smiles>NC(P)C(O)c1ccccc1O</smiles>

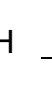<smiles>[Mg][Ba][Ba]</smiles>
$-10^{\circ} \mathrm{C}$<smiles></smiles>

Yield $97 \%$ ee $96 \%$

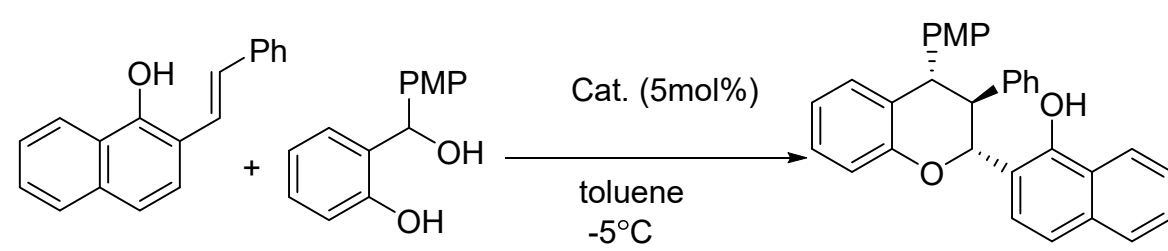

Yield $90 \%$ ee $\quad 95 \%$<smiles>[R]c1cc2ccccc2cc1OP(=O)(O)Oc1c(OP(=O)(O)O)c([R])cc2ccccc12</smiles>

Cat. $\mathrm{R}=2,4,6,-(i \operatorname{Pr})_{3} \mathrm{C}_{6} \mathrm{H}_{2}$<smiles>O=P(O)(O)Oc1c(Br)ccc2c1Oc1c(Br)cccc1CC2</smiles>

Cat. $\mathrm{Ar}=3,5-\left(\mathrm{CF}_{3}\right)_{2} \mathrm{C}_{6} \mathrm{H}_{3}$

Scheme 9. The research of Zhihui Shao's group<smiles>COc1ccc2ccccc2c1/C=C/c1ccccc1</smiles><smiles>[18FH]</smiles><smiles>Oc1ccccc1C(O)P</smiles>

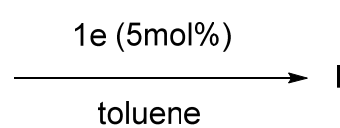
$-10^{\circ} \mathrm{C}$<smiles>Oc1ccc2ccccc2c1/C=C/c1ccccc1</smiles><smiles>COc1ccccc1C(O)C(=O)O</smiles>

N.R.

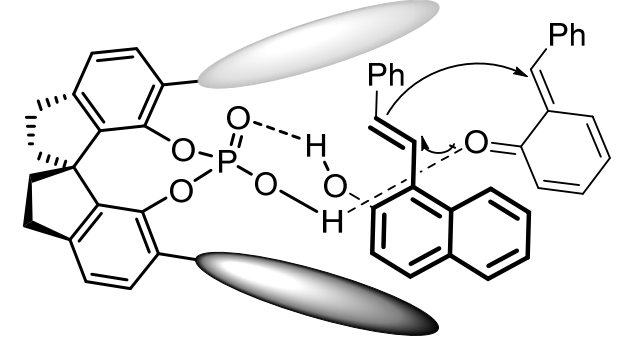

Scheme 10. Exploring experiments and plausible transition states

F-C reaction, hydrogen atoms in aromatic compounds and directional heterocyclic compounds are replaced by active olefins, halogenated hydrocarbons, carbonyl compounds and imines [43-47].

Friedel Crafts $(\mathrm{F}-\mathrm{C})$ reaction is a common reaction to construct $\mathrm{C}-\mathrm{C}$ bond on aryl group in organic synthesis. In 
Indoles are widely distributed in bioactive molecules as skeletons or functional groups (Figure. 4). Alkaloids<smiles>CC(C)(C)C(=O)N[C@@H](Cc1c[nH]c2ccccc12)C(=O)N[C@@H](Cc1c[nH]c2ccccc12)NC=O</smiles>

Macimorelin Growth hormone deficiency<smiles>CN(C)CCc1c[nH]c2ccc(C[C@@H]3COC(=O)N3)cc12</smiles><smiles>CCc1cccc2c3c([nH]c12)C(CC)(CC(=O)O)OCC3</smiles>

Etodolac

Zolmitriptan Treats migraine headaches in adults containing indole structure showed antifungal, anticancer, antimalarial and antibacterial activities [48-51].

Figure 4. The clinically used indole-containing drugs<smiles>CN1CC(=O)N2C(Cc3c([nH]c4ccccc34)[C@H]2c2ccc3c(c2)OCO3)C1=O</smiles>

5-Hydroxytryptophan Treats depression or fibromyalgia
In 2010, Lin Xufeng's group developed the F-C reaction of indole and imine catalyzed by spirodiindene skeleton chiral phosphoric acid [6], which has a high degree of corresponding selection, and can obtain the highest yield of $97 \%$ and the highest ee value of $99 \%$. (scheme 11) $\beta$ - carbazoline compounds are important pharmacological active components in indole alkaloids, which widely exist in natural products and drugs [44, 5257]. In 2017, Lin Xufeng's group further explored the aza Friedel Crafts reaction of indole and 1-trifluoromethyl3,4 -dihydro- $\beta$ - carboline catalyzed by SPA [58], and obtained high yield (81\%) and corresponding selectivity $(86 \%$ ee), and proposed intermediate transition state. (Scheme 12)<smiles>[R][R]1cccc(/C=N/S(=O)(=O)c2ccc([R])cc2)c1</smiles><smiles>O=P(O)(O)Oc1c(Br)ccc2c1C13CCCc4ccc(Br)c(c41)CC23</smiles>

Cat.

Ar=1-naphthyl

Scheme 11. First SPA catalyzed F-C reaction of indole and imine

In 2017, the Gredicak Matija's group provided an aza Friedel Crafts reaction for the preparation of chiral $\alpha$ tetrasubstituted (3-indolyl) - (diaryl) methylamines [59]. Before that, there was no synthesis method with high corresponding selectivity [60-61]. By using N-protected isoindolinol and $\mathrm{N}$-protected indole to catalyze the reaction respectively, the group of Gredicak Matija pointed out that the chiral phosphoric acid catalyst connects the $\mathrm{H}$ atoms on the $\mathrm{N}$ of two substrates to form a transition state for catalytic reaction. (Scheme 13)<smiles>FC(F)(F)C1=NCCc2c1[nH]c1ccccc21</smiles><smiles>c1ccc2[nH]ccc2c1</smiles>

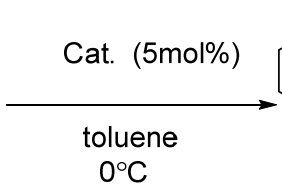
$0^{\circ} \mathrm{C}$
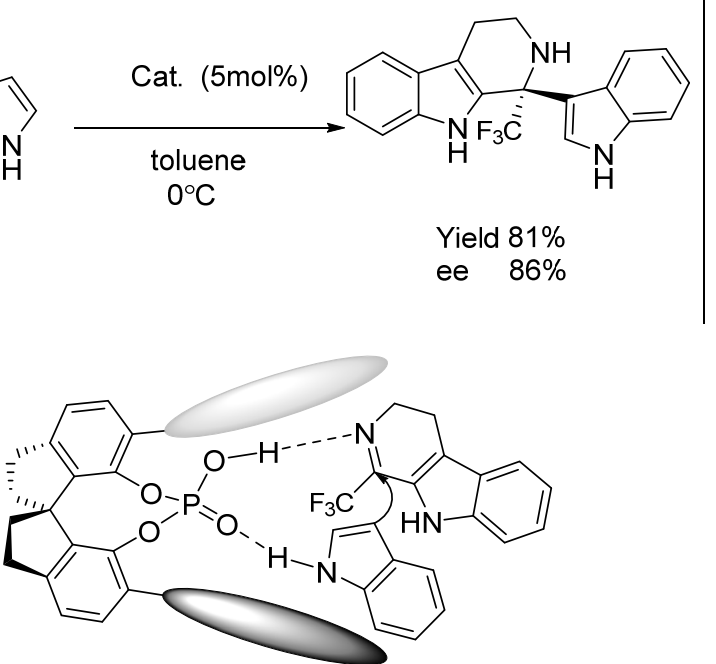

Scheme 12. Enantioselective aza-Friedel-Crafts reaction

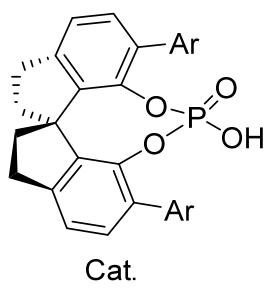

$\mathrm{Ar}=3,5^{-}\left(\mathrm{CF}_{3}\right)_{2} \mathrm{C}_{6} \mathrm{H}_{3}$ 
<smiles>O=C1NC(O)(c2cc[R]cc2)c2ccccc21</smiles><smiles>[R1]1ccc2[nH]ccc2c1</smiles>

Cat. $(5 \mathrm{~mol} \%)$<smiles>[R1]c1ccc([C@]2(c3ccccc3)NC(=O)c3ccccc32)cc1</smiles>

up to $98 \%$ yield up to $>99: 1$ e.r.<smiles>CN1C(=O)c2ccccc2C1(O)c1ccccc1</smiles>

Cat. (5mol\%)

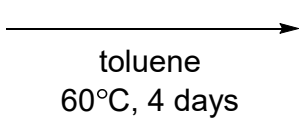

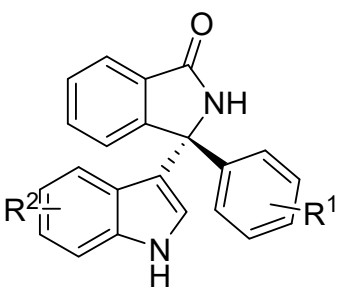<smiles>O=P(O)(O)Oc1c(Br)ccc2c1C13CCCc4ccc(Br)c(c41)CC23</smiles>

Cat. $\mathrm{Ar}=4-\mathrm{ClC}_{6} \mathrm{H}_{4}$

\section{$88 \%$ yield} 63:37 e.r.<smiles>CN1C(=O)c2ccccc2C1(O)c1ccccc1</smiles>

Cat. (5mol\%)<smiles></smiles>

$$
\begin{aligned}
& 81 \% \text { yield } \\
& 53: 47 \text { e.r. }
\end{aligned}
$$

Scheme 13. The research of Gredicak Matija's Group

$\mathrm{N}$-substituted indoles and carbazole are the main components of some natural products and bioactive molecules, which are widely used in pharmaceutical chemistry and material chemistry [62-63]. In 2017, sun Jianwei's group used SPA to catalyze N-alkylation of<smiles>[R1]Nc1ccc(C(O)c2ccccc2)cc1</smiles><smiles>[R]c1[nH]c2cc[R1]cc2c1[R4]</smiles><smiles>[R7]Nc1ccc(C(c2ccccc2)n2c([R4])c([R3])c3ccccc32)cc1</smiles>

$$
\text { up to } 98 \% \text { yield }
$$
up to $99 \%$ ee

indoles and carbazole compounds [64], and obtained high yield and high enantioselectivity under mild conditions. It provides a new idea for asymmetric $\mathrm{N}$-alkylation of indole and carbazole. (Scheme 14)<smiles>O=P(O)(O)Oc1c(Br)ccc2c1Oc1c(Br)cccc1CC2</smiles>

Cat.

Scheme 14. Asymmetric N-Alkylation of Indoles and Carbazoles through SPAs

Chiral disubstituted carbonyl indoles are important bioactive molecules [65]. In 2018, Lin Xufeng's team reported the first case of using chiral SPA to catalyze the 1,6-conjugate addition of indole to the unprotected indirubin derivative structure on $\mathrm{N}$ [66], and obtained good yield and corresponding selectivity (up to $97 \%$ ee). (Scheme 15) 

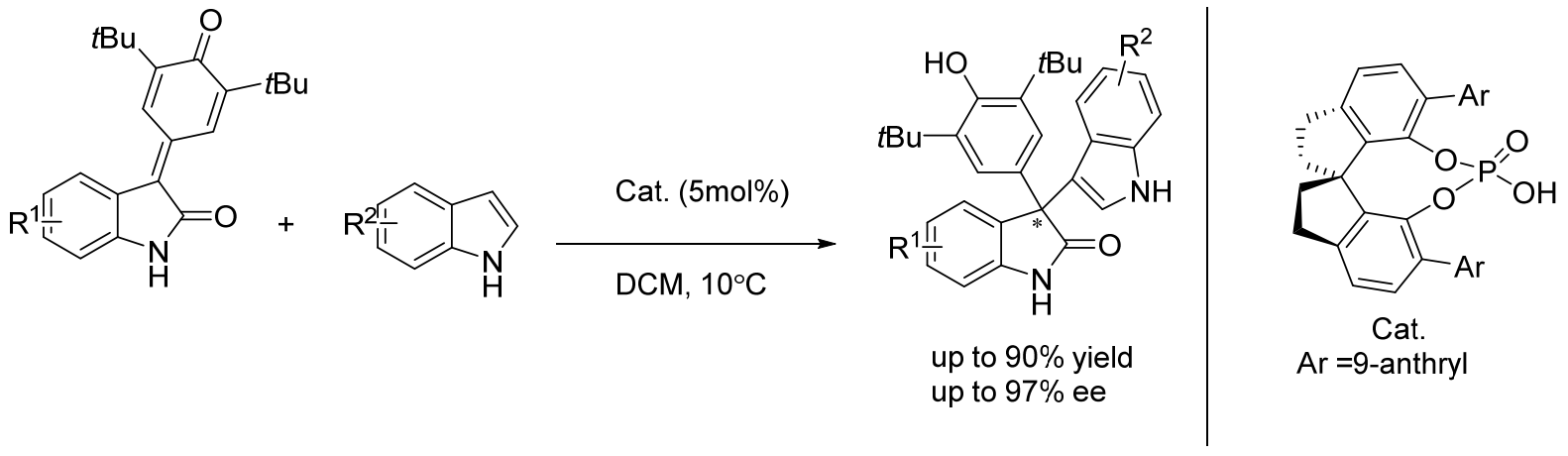

Scheme 15. Asymmetric organocatalytic synthesis of chiral 3,3-disubstituted oxindoles

In 2019, Zhao Junling and his colleagues used SPA as catalyst and trifluoromethyl ketone as electrophilic reagent to realize the F-C reaction on the 7th position of indole [67]. Good results have been obtained, and the possible mechanism has been discussed in connection with the experimental results and the previous report [68]. In this reaction, SPA catalyst, as a bifunctional catalyst, activates the substrate through hydrogen bonding. In addition to the traditional nucleophilic $\mathrm{C} 3$ site, the $\mathrm{C} 7$ site of indole is also activated by the para activation of the amino part. Moreover, due to the steric hindrance caused by the substituted amino part at the $\mathrm{C} 4$ position, the alkylation at the $\mathrm{C} 7$ position prevails, which makes the product have good regioselectivity. (Scheme 16)<smiles>[R]Nc1cccc2[nH]c([R])c(C)c12</smiles><smiles>[R]Nc1ccc([C@]([R])(O)C(F)(F)F)c2[nH]c([R])c([R])c12</smiles>

up to $98 \%$ yield up to $99 \%$ ee<smiles></smiles>

Cat. $\mathrm{Ar}=2,4,6-(\operatorname{Pr})_{3} \mathrm{C}_{6} \mathrm{H}_{2}$<smiles>[R]Nc1cccc2c1ccn2CCCCCCC(=O)c1ccccc1</smiles><smiles>[R]Nc1ccc([C@](O)(c2ccccc2)C(F)(F)F)c2[nH]ccc12</smiles>

C7 alkylation

Scheme 16. C7-Friedel-Crafts alkylation of indoles

\subsection{Other catalytic reactions}

Fischer indolization is a simple synthesis of indole by cyclization of aromatic hydrazones of aldehydes or ketones under acidic conditions. In 2011, the list team reported the first case of asymmetric Fischer indole reaction catalyzed by SPA, in which phenylhydrazones derived from 4-substituted cyclohexanones had high corresponding selectivity [69]. (Scheme 17)<smiles>[R]C1CCC(=NN([R])c2cc[R1]cc2)CC1</smiles>

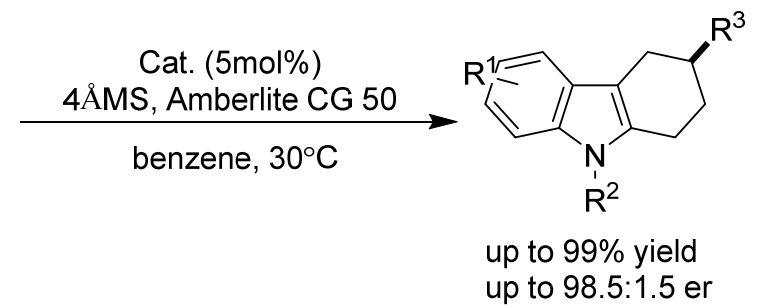<smiles>O=P(O)(O)Oc1c(Br)ccc2c1C1c3c(Br)ccc(Br)c3C1CC2</smiles>

Cat. $\operatorname{Ar}=9$-anthryl

Scheme 17. Fischer indolization 
Pictet Spengler reaction is a common method to synthesize $\beta$ - carbazoline compounds. In 2012, Lin Xufeng's team reported the Pictet Spengler reaction for the

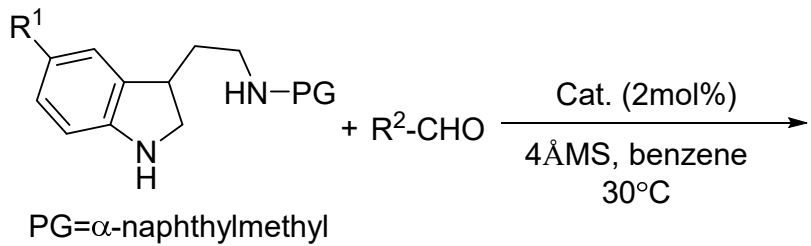

synthesis of tetrahydro $-\beta$ - carbazoline with high enantioselectivity using SPA catalyst[70]. (Scheme18)

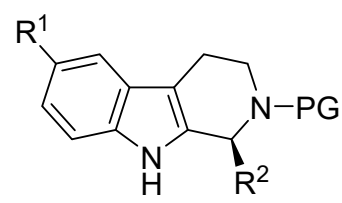

up to $99 \%$ yield up to $98 \%$ ee

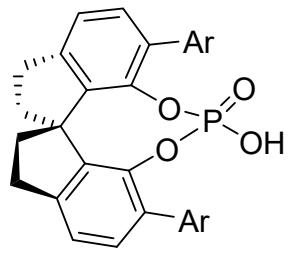

Cat.

Scheme 18. Pictet-Spengler reaction

SPA is also suitable for a variety of dual catalytic systems [71-73]. In 2019, Jiang Zhiyong's group published Povarov reaction without transition metal catalysis [74]. Under the catalysis of SPA and DPZ, a series of chiral isoindoline-1-ones were synthesized under the influence of visible light, and the highest yield of $97 \%$ and ee value of $98 \%$ were obtained. (scheme 19) These dual catalytic systems also provide more ideas for the application and development of SPA catalysts.<smiles>CC(NC(=O)OCc1ccccc1)C(=O)Oc1ccc2[nH]ccc2c1</smiles>

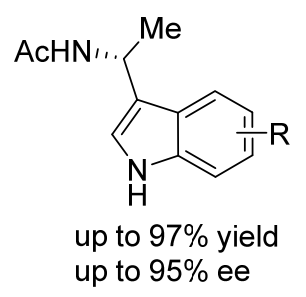<smiles>O=P1(OCl)Oc2c(Br)ccc3c2C2(CCCc4ccc(Br)c(c42)O3)O1</smiles>

Cat. $\mathrm{Ar}=2,4,6-(\operatorname{Pr})_{3} \mathrm{C}_{6} \mathrm{H}_{2}$

Scheme 19. Povarov reaction

\section{Conclusion}

Although SPA catalyst has only been developed for ten years, it has attracted wide attention as a new chiral phosphoric acid catalyst. Because of the safety and environmental protection, it is very suitable for the synthesis of drug molecules, and provides a new synthetic idea for a variety of compounds with pharmacological activities. As a young chiral phosphoric acid catalyst, SPA catalyst has developed a second-generation catalyst based on the original framework, with the development of applied chemistry, more efficient, mild and green SPA catalysts will be developed and more applications will emerge. However, it should also be noted that the limitations of the current catalytic reaction, most of the reports have not reached the gram level reaction, there are still many limitations to achieve industrial production.

\section{Acknowledgments}

I wish to thank my lab colleagues for their help in my research and my families for their supports.

\section{References}

[1] Takahiko, A., Junji, I., Koji, Y., et al.(2004)Enantioselective mannich-type reaction catalyzed by a chiral brønsted acid. J. Angewandte Chemie-International Edition, 43(12): 1566-1568.

[2] Stephen, J.C. (2006) Chiral phosphoric acids: powerful organocatalysts for asymmetric addition reactions to imines. J. Angewandte Chemie International Edition, 45(24): 3909-3912.

[3] Dixit, P., Erli, S., Sadiya, R., et al. (2004) Complete field guide to asymmetric BINOL-phosphoate derived brønsted acid and metal catalysis: history and classification by mode of activation; Bronsted acidity, hydrogen bonding, ion pairing, and metal phosphates. J. Chemical Reviews, 114(18): 9047-9153.

[4] Bao, J.M., Wulff, W.D., Dominy, J.B., et al. (1996) Synthesis, resolution, and determination of absolute configuration of a vaulted 2,2'-binaphthol and a vaulted 3,3'-biphenanthrol (VAPOL). J. Journal of The American Chemical Society, 118(14): 3392-3405.

[5] Rahman, A., Lin, X.F. (2018) Development and application of chiral spirocyclic phosphoric acids in asymmetric catalysis. J. Organic \& Biomolecular Chemistry, 16(26): 4753-4777.

[6] Xu, F.X., Huang, D., Han, C., et al. (2010) SPINOLDerived phosphoric acids: synthesis and application in enantioselective friedel-crafts reaction of indoles with imines. J. Journal of Organic Chemistry, 75(24): 8677-8680.

[7] HUANG D, XU F X, LIN X F, et al. The preparation 
method and applications of the chiral spirocyclic phosphoric acid: CN102030780A[P]. 2010-10-26.

[8] Coric, I., Muller, S., List, B. (2010) Kinetic resolution of homoaldols via catalytic asymmetric transacetalization. J. Journal of The American Chemical Society, 132(49): 17370-17373.

[9] Masahiro, Y., Junji, I., Kohei, F., et al. (2007) Chiral brønsted acid catalyzed enantioselective mannichtype reaction. J. Journal of The American Chemical Society, 129(21): 6756-6764.

[10] Malakar, S., Sowndarya, S.V.S., Sunoj, R.B. (2018) A quantification scheme for non-covalent interactions in the enantio-controlling transition states in asymmetric catalysis. J. Organic \& Biomolecular Chemistry, 16(31): 5643-5652.

[11] Huang, D., Xu, F.X., Lin, X.F., et al. (2012) Highly enantioselective pictet-spengler reaction catalyzed by SPINOL-phosphoric acids. J. Chemistry-A European Journal, 18(11): 3148-3152.

[12] Seguin, T.J., Lu, T.X., Wheeler, S.E. (2015) Enantioselectivity in catalytic asymmetric fischer indolizations hinges on the competition of $\pi$-stacking and $\mathrm{CH} / \pi$ interactions. J. Organic Letters, 17(12): 3066-3069.

[13] Varlet, T., Gelis, C., Retailleau, P., et al. (2020) Enantioselective redox-divergent chiral phosphoric acid catalyzed quinone Diels-Alder reactions. J. Angewandte Chemie-International Edition, 59(22): 8491-8496.

[14]Zhang, J., Wang, Y.Y., Sun, H., et al. (2020) Enantioselective three-component Ugi reaction catalyzed by chiral phosphoric acid. J. Science ChinaChemistry, 63(1): 47-54.

[15] Wang, L., Zhong, J.L., Lin, X.F. (2019) Atroposelective phosphoric acid catalyzed threecomponent cascade reaction: enantioselective synthesis of axially chiral N-Arylindoles. J. Angewandte Chemie-International Edition, 58(44): 15824-15828.

[16] Kal-Koshvandi, A.T., Heravi, M.M. (2019) Applications of dainshefsky's dienes in the asymmetric synthesis of aza-diels-alder reaction. J. Chemical Record, 19(2-3): 550-600.

[17] Chen, Z.L., Wang, B.L., Wang, Z.B., et al. (2013) Complex bioactive alkaloid-type polycycles through efficient catalytic asymmetric multicomponent azadiels-alder reaction of indoles with oxetane as directing group. J. Angewandte Chemie-International Edition, 52(7): 2027-2031.

[18] Anas, S., Kagan, H.B. (2009) Routes toward enantiopure 2-substituted indolines: an overview. J. Tetrahedron-Asymmetry, 20(19): 2193-2199.

[19]Liu, D.Y., Zhao, G.W., Xiang, L. (2010) Diverse strategies for the synthesis of the indoline scaffold. J. European Journal of Organic Chemistry, 21: 39753984.

[20] Cheng, P., Huang, N., Jiang, Z.Y., et al. (2008) 1-aryltetrahydroisoquinoline analogs as active anti-HIV agents in vitro. J. Bioorganic \& Medicinal Chemistry Letters, 18(7): 2475-2478.

[21] Scott, J.D., Williams, R.M. (2002) Chemistry and biology of the tetrahydroisoquinoline antitumor antibiotics. Chemical Review, 102(5): 1669-1730.

[22]Zhang, Y.J., Feng, J.H., Jia, Y.P., et al. (2011) Development of tetrahydroisoquinoline-based hydroxamic acid derivatives: potent histone deacetylase inhibitors with marked in vitro and in vivo antitumor activities. J. Journal of Medicinal Chemistry, 54(8): 2823-2838.

[23] Aper,s S., Pape,r D., Burgermeister, J., et al. (2002) Antiangiogenic activity of synthetic dihydrobenzofuran lignans. J. Journal of Natural Products, 65(5):718-720.

[24] Trost, B.M., Thiel, O.R., Tsui, H.C. (2003) Total syntheses of furaquinocin A,B, and E. J. Journal of the American Chemical society, 125(43): 1315513164.

[25]Lachia, M., Moody, C.J. (2008) The synthetic challenge of diazonamide $\mathrm{A}$, a macrocyclic indole bis-oxazole marine natural product. J. Natural Product Reports, 25(2): 227-253.

[26] Shen, T., Wang, X.N., Lou, H.X. (2009) Natural stilbenes: an overview. J. Natural Product Reports, 26(7): 916-935.

[27] Xiang, W.J., Ma, L., Hu, L.H. (2010) Neolignans and flavonoids from the root bark of illicium henryi. J. Fitoterapia, 81(8): 1228-1231.

[28]Feng, W.S., Zang, X.Y., Zheng, X.K., et al. (2010) Two new dihydrobenzofuran lignans from rabdosia lophanthoides (Buch. - Ham. Ex D. Don) hara. J. Journal of Asian natural products research, 12(7): 557-561.

[29] Gelis, C., Bekkaye, M., Lebee, C., et al. (2016) Chiral phosphoric acid catalyzed [3+2] cycloaddition and tandem oxidative [3+2] cycloaddition: asymmetric synthesis of substituted 3-aminodihydrobenzofurans. J. Organic Letters, 18(14): 3422-3425.

[30]Liang, W.J., Geng, C.A., Zhang, X.M., et al. (2014) (+/-)-Paeoveitol, a pair of new norditerpene enantiomers from Paeonia veitchii. J. Organic Letters, 16(2): 424-427.

[31]Liang, W.J., Ma, Y.B., Geng, C.A., et al. (2015) Paeoveitols A-E from Paeonia veitchii. J. Fitoterapia, 106: 36-40.

[32]Li, T.Z., Geng, C.A., Yin, X.J., et al. (2017) Catalytic asymmetric total synthesis of (+)- and (-)-paeoveitol via a hetero-Diels-Alder reaction. J. Organic Letters, 19(3): 429-431.

[33]Zhang, Y.H., Guo, Y.H., Li Z.L., et al. (2016) Biomimetic total synthesis of paeoveitol. J. Organic Letters, 18(18): 4578-4581.

[34]Nakata ,T. (2005) Total syntheses of marine polycyclic ethers. J. Chemical Reviews, 105(12): 4314-4347.

[35] Inoue, M. (2005) Convergent strategies for syntheses of trans-fused polycyclic ethers. J. Chemical Reviews, 
105(12): 4379-4405.

[36]Nicolaou, K.C., Frederick, M.O, Aversa, R.J. (2008) The continuing saga of the marine polyether biotoxins. J. Angewandte Chemie-International Edition, 47(38): 7182-7225.

[37] Ota, Y., Kondoh, A., Terada, M. (2018) Enantioselective intramolecular nicholas reaction catalyzed by chiral phosphoric Acid: enantioconvergent synthesis of seven-membered cyclic ethers from racemic diols. J. Angewandte Chemie-International Edition, 57(42): 1391713921.

[38] Salae, A.W., Chairerk, O., sukkoet, P., et al. (2017) Antiplasmodial dimeric chalcone derivatives from the roots of Uvaria siamensis. J. Phytochemistry, 135:135-143.

[39]Zhai, Y.M., Jiang, K., Qu, S.J., et al. (2016) Structurally diverse stilbene dimers from Gnetum montanum Markgr.: studies on the H-1 chemical shift differences between dimeric stilbene epimers correlating to the relative configurations. J. RSC Advanves, 6(55): 50083-50090

[40] Kumar, S., Deshpande, S., Chandra, V., et al. (2009) Synthesis and biological evaluation of 2,3,4triarylbenzopyran derivatives as SERM and therapeutic agent for breast cancer. J. Bioorganic \& Medicinal Chemistry, 17(19): 6832-6840.

[41] You ,Y., Li, T.T., Yuan, S.P., et al. (2020) Catalytic asymmetric [4+2] cycloaddition of 1-((2aryl)vinyl)naphthalen-2-ols with in situ generated ortho-quinone methides for the synthesis of polysubstituted chromanes. J. Chemical Communications, 56(3): 439-442.

[42]Feng, S., Yang, B., Chen, T., et al. (2020) Catalytic asymmetric $[4+2]$ cycloaddition of ortho-alkenyl naphthols/phenols with ortho-quinone methides: highly stereoselective synthesis of chiral 2,3,4trisubstituted chromans. J. The Journal of organic chemistry, 85(8): 5231-5244.

[43]Cacchi, S., Fabrizi, G. (2005) Synthesis and functionalization of Indoles through palladiumcatalyzed reactions. J. Chemical Reviews, 105(7):2873-2920.

[44] Somei, M., Yamada, F. (2004) Simple indole alkaloids and those with a nonrearranged monoterpenoid unit. J. Natural Product Reports. 21(2): 278-311.

[45] O'connor, S.E., Maresh, J.J. (2006) Chemistry and biology of monoterpene indole alkaloid biosynthesis. J. Natural Product Reports, 23(4): 532-547.

[46] Humphrey, G.R., Kuethe, J.T. (2006) Practical methodologies for the synthesis of indoles. J. Chemical Reviews, 106(7): 2875-2911.

[47] Chen, Y.C., Xie, Z.F. (2012) Research progress in friedel-crafts reaction of indoles and imines. $J$. Chinese Journal of Organic Chemistry, 32(3): 462471.

[48]Fang, L., Tian, S.M., Zhou, J., et al. (2016)
Melaxillines A and B, monoterpenoid indole alkaloids from melodinus axillaris. J. Fitoterapia, 115: 173-176.

[49]Long, S.Y., Li, C.L., Hu, J., et al. (2018) Indole alkaloids from the aerial parts of Kopsia fruticosa and their cytotoxic, antimicrobial and antifungal activities. J. Fitoterapia, 129: 145-149.

[50] Wan, Y.C., Li, Y.H., Yan, C.X., et al. (2019) Indole: A privileged scaffold for the design of anti-cancer agents. J. European Journal of Medicinal Chemistry, $183,111691$.

[51]Ciulla, M.G., Kumar, K. (2018) The natural and synthetic indole weaponry against bacteria. J. Tetrahedron Letters, 59(34): 3223-3233.

[52] Kawasaki, T., Higuchi, K. (2005) Simple indole alkaloids and those with a nonrearranged monoterpenoid unit. J. Natural Product Reports, 22(6): 761-793.

[53] Inman, W.D., Bray, W.M., Gassner, N.C., et al. (2010) A beta-Carboline alkaloid from the papua new guinea marine sponge hyrtios reticulatus. J. Journal of Natural Products, 73(2): 255-257.

[54]Benrley, K.W. (2004) Beta-phenylethylamines and the isoquinoline alkaloids. J. Natural Product Repports, 21(3): 395-424.

[55] Guang, H.J., Chen, H.S., Peng, W.L., et al. (2006) Design of beta-carboline derivatives as DNAtargeting antitumor agents. J. European Journal of Medicinal Chemistry, 41(10): 1167-1179.

[56]Boursereau, Y., Coldham, I. (2004) Synthesis and biological studies of 1-amino beta-carbolines. J. Bioorganic \& Medicinal Chemistry Letters, 14(23): 5841-5844.

[57]Liu, F., Yu, L.Q., Jiang, C., et al. (2010) Discovery of tetrahydro- beta-carbolines as inhibitors of the mitotic kinesin KSP. J. Bioorganic \& Medicinal Chemistry Letters, 18(12): 4167-4177.

[58]Xie, E., Rahman, A., Lin, X.F. (2017) Asymmetric synthesis of CF3- and indole-containing tetrahydrobeta-carbolines via chiral spirocyclic hosphoric acidcatalyzed aza-Friedel-Crafts reaction. J]. Organic Chemistry Frontiers, 4(7): 1407-1410.

[59] Glavac, D., Zheng, C., Dokli, I., et al. (2017) Chiral bronsted acid catalyzed enantioselective aza-friedelcrafts reaction of cyclic alpha-diaryl N-acyl imines with indoles. J. Journal of Organic Chemistry, 82(16): 8752-8760.

[60] Aranzamendi, E., Sotomayor, N., Lete, E. (2012) Bronsted acid catalyzed enantioselective alphaamidoalkylation in the synthesis of isoindoloisoquinolines. J. Journal of Organic Chemistry, 77(6): 2986-2991.

[61] Yu, X.L., Wang, Y.M., Wu, G.P., et al. (2011) Organocatalyzed enantioselective synthesis of quaternary carbon-containing isoindolin-1-ones. $\mathrm{J}$. European Journal of Organic Chemistry, 16: 30603066. 
[62] Shiri, M. (2012) Indoles in multicomponent processes (MCPs). J. Chemical Reviews, 112(6): 3508-3549.

[63] Kochanowska-Karamyan, A.J., Hamann, M.T. (2010) Marine indole alkaloids: potential new drug leads for the control of depression and anxiety. J. Chemical Reviews, 110(8): 4489-4497.

[64] Chen, M., Sun, J.W. (2017) Catalytic asymmetric Nalkylation of indoles and carbazoles through 1,6conjugate addition of aza-para-quinone methides. J. Angewandte Chemie -International Edition, 56(16): 4583-4587.

[65] Galliford, C.V., Scheidt, K.A. (2007) Pyrrolidinylspirooxindole natural products as inspirations for the development of potential therapeutic agents. J. Angewandte Chemie -International Edition, 46(46): 8748-8758.

[66]Rahman, A., Zhou, Q.X., Lin, X.F. (2018) Asymmetric organocatalytic synthesis of chiral 3,3disubstituted oxindoles via a 1,6-conjugate addition reaction. J. Organic \& Biomolecular Chemistry, 16(29): 5301-5309.

[67] Cai, L., Zhao, Y.L., Huang, T.K., et al. (2019) Chiral phosphoric-acid- catalyzed regioselective and enantioselective C7-friedel-crafts alkylation of 4aminoindoles with trifluoromethyl ketones. J. Organic Letters, 21(10): 3538-3542.

[68]Fu, A.P., Meng, W., Li ,H.L., et al. (2014) A density functional study of chiral phosphoric acid-catalyzed direct arylation of trifluoromethyl ketone and diarylation of methyl ketone: reaction mechanism and the important role of the CF3 group. J. Organic \& Biomolecular Chemistry, 12(12): 1908-1918.

[69] Muller, S., Webber, M.J., List, B. (2011) The catalytic asymmetric fischer indolization. J. Journal of The American Chemical society, 133(46): 18534-18537.

[70]Huang, D., Xu, F.X., Lin, X.F., et al. (2012) Highly enantioselective pictet-spengler reaction catalyzed by SPINOL-phosphoric acids. J. Chemisry-A European Journal, 18(11): 3148-3152.

[71] Xu, B., Zhu, S.F., Xie, X.L., et al. (2011) Asymmetric $\mathrm{N}-\mathrm{H}$ insertion reaction cooperatively catalyzed by rhodium and chiral spiro phosphoric acis. J. Angewandte Chemie -International Edition, 50(48): 11483-11486.

[72] Kisan, H.K., Sunoj, R.B. (2014) Deciphering the origin of cooperative catalysis by dirhodium acetate and chiral spiro phosphoric acid in an asymmetric amination reaction. J. Chemical Communications, 50(93): 14639-14642.

[73]Zhang, Y.L., Yao, Y., He, L., et al. (2017) Rhodium(II)/chiral phosphoric acid-cocatalyzed enantioselective $\mathrm{O}-\mathrm{H}$ bond insertion of alpha-diazo esters. J. Advances Synthesis \& Catalysis, 359(16): 2754-2761.

[74] Shen, M.L., Shen, Y., Wang, P.S. (2019) Merging visible-light photoredox and chiral phosphate catalysis for asymmetric friedel-crafts reaction with in situ generation of N-acyl lmines. J. Organic Letters, 21(9): 2993-2997. 